Publisher homepage: www.universepg.com, ISSN: 2707-4668 (Online) \& 2707-465X (Print)

https://doi.org/10.34104/ajssls.020.056062

Asian Journal of Social Sciences and Legal Studies

Journal homepage: www.universepg.com/journal/ajssls

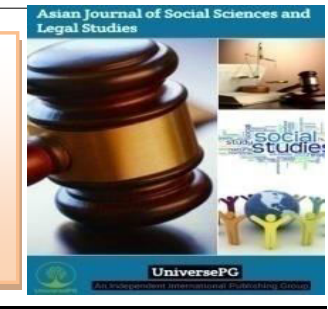

\title{
Effectiveness of Microfinance on Household Income Generation Strategy in the Southwest Region of Bangladesh
}

\author{
Sudipa Basu ${ }^{1}$, Apurba Roy ${ }^{1}$, and Sanjit Karmokar ${ }^{2}$ \\ ${ }^{1}$ Department of Economics, University of Barishal, Barishal-8200, Bangladesh; and ${ }^{2}$ Assistant Director of Community \\ Engagement, Bangladesh Relief Initiative for Communities in Khulna (BRICK), Inc. Virginia, USA. \\ *Correspondence: aroy@bu.ac.bd (Apurba Roy, Assistant Professor, Dept. of Economics, University of Barishal, Barishal, \\ Bangladesh)
}

\begin{abstract}
The primary purpose of the study is to evaluate the effectiveness of microfinance on household income generation in the south-west region of Bangladesh. A set of statistical tools such as descriptive analysis, $t$-test, correlation analysis and log-linear multiple regression models have been used to achieve the objective of the study. It has been found that the difference between household income, expenditure, saving, working hours and capital is statistical and significant after joining the microfinance program. Also, results from correlation analysis show a positive and meaningful relationship between credit and household monthly income, expenditure, and savings. Besides, the regression analysis confirms that the age of the respondent, family members and loan amount have a positive and statistically significant impact on income generation for the microfinance receiver. The finding of the research is crucial and meaningful to the policymaker to take practical steps in reducing poverty and sustainable rural development.
\end{abstract}

Keywords: Effectiveness, Microfinance, Household income, Southwest region, Strategy, MFI, and Bangladesh.

\section{INTRODUCTION}

Microfinance is not a new concept. In the mid $17^{\text {th }}$ century, small microcredit operations have been started (Kaburi et al., 2013). It refers to formal financial services including loans, savings, insurance, and transfer services provided to the poor, low-income, and disadvantaged households who are not backed up by the mainstream banking system (Hossain et al., 2019). Although microcredit and microfinance are often used interchangeably, they are not same. Sinha, (1998) concludes microcredit as a small loan provided by microfinance and credit institutions. So, microcredit is one kind of financial service which incorporates microfinance (Nawaz, 2010).
On the other, microfinance is the provision of financial services which are provided to poor people (Otero, 1999). Generally, these services include deposits, loans, savings, money transfers, payment services and insurance (Arora and Singhal, 2013; Ledgerwood et al., 2013). Microfinance is also a crucial instrument in national economic growth and poverty reduction among poor and near-poor households. The initial focus of the microfinance institutions (MFIs) was to provide small loans and microcredit. Later, they realized that poor people often required a set of financial services which helps to improve their lives. In this way, the microcredit evolved in microfinance (Ledgerwood et al., 2013). 
Microfinance services have been successfully used to reduce poverty in many developing countries like Bangladesh, India, Indonesia, and South African countries (Rahman and Mazlan, 2014). More than 90 percent of people have no direct access to the formal financial institution in developing countries (Robinson 2001), which makes them more poor day by day (Smith and Thurman, 2007). Also, they have been excluded from the formal financial institutions to get easy financial access (Chirwa, 2002). A lot of strategies have been implemented to reduce poverty from developing countries. Among them, providing credit to poor under microfinance programs is remarkable (ADB, 2000; Olivares and Santos, 2009). In this situation, microfinance has emerged as an essential and significant source of finance for these people (ADB, 2000).

Nowadays, poverty and unemployment are a ubiquitous word in the academic world. According to research, about 1.6 billion people on the globe are in absolute poverty, and the number is rising continuously (Addae-Korankye, 2012). It is imperative to help these poor people to upgrade their livelihood. Most of the developing counties try to alleviate poverty through fund allocation in their national budget. However, it is not so easy to help the poor people as poverty is embedded in our socioeconomic system for a long time. A lot of tools and policies are used to improve the conditions of poor people. Among them, microfinance service is one of the key ways. Hermes and Lensink (2007) state the finical system, which emphasizes sustainable microfinance program, is undoubtedly overcome the poverty situation. Bebczuk and Haimovich (2007) provide evidence that credit helps to increase labour income to those who have access to it compared to those people who have no access to credit.

It is no surprise that in the last decades there is tremendous emergence of microfinance institutions that have played a significant role in increasing income and employment opportunities to poor people, especially women, in many developing countries (Nawaz, 2015). According to Morduch and Haley (2002), the extensive and robust evidence that microcredit positively influenced to achieve the first
MDG goal, this is to eradicate poverty (Morduch, 1999). A village study in Bangladesh by (Nawaz, 2010) finds that microfinance has led to a moderate reduction of poverty level of the borrowers. Another survey by (Mazumder and Wencong, 2015) shows that microfinance has positive role in increasing the economic empowerment of the recipients. Moreover, micro-finance enhances the socio-cultural empowerment, and it can be an essential tool of women empowerment in rural Bangladesh (Nawaz, 2015). Also, microfinance has been a proven tool to increase the income and savings of low-income households (Silva, 2012).

Microfinance program has contributed to achieving several objectives of Millennium Development Goals (MDGs), including poverty alleviation through income generation. Taking the consecutive success stories of countries like Ghana, Pakistan and Bolivia, many developing countries including Bangladesh have officially recognized microfinance as one of the interventions to reduce poverty (Addae-Korankye, 2012; Khan and Rahaman, 2007). There is a close relationship between income generation and rural development (Winters et al., 2002). Since most of the people of Bangladesh live in rural areas, any income generation activities in these areas accelerate to the process of rural development. As agricultural development implies the increase in the income of the country people along with the improvement in the rural infrastructures, opportunities of employment facility accelerated by microfinance is undoubtedly a useful instrument (Ubagu and Gbuushi, 2020). It is the sources of financial support through which rural people can quickly and actively take part in various income-generating activities. Research on microfinance and household income generation based in the south-west region of Bangladesh is limited in the academic literature. Hence, the current study concentrates on investigating microfinance and its impact on household income generation in the context of the south-western part of Bangladesh.

\section{METHODOLOGY}

Study area and sample selection: Multistage sampling technique has been applied to select the study area. In the first stage, Khulna district has been chosen 
from the total 64 districts in Bangladesh. In the next step, Dighalia Upazila has been randomly selected from a total of nine Upazila in Khulna District. This Upazila has six unions, namely Dighalia, Senhati, Barakpur, Gazirhat, Aaronghata, Jugipole. In the last stage, Barakpur union has been purposively selected as a study area to collect the data. In the study area, about 900 households have taken a loan from the MFI and rest households are not made microfinance. Then among them, 39 households randomly have been chosen who have taken microfinance. In the same way, data have been collected from 39 households randomly who have not taken microfinance. Data required for research have been collected from primary sources as well as secondary sources. Pre-tested questionnaire from a pilot survey in the study area has been used to collect data from the respondents at the time of the field survey. Besides, secondary data have been collected from different assessment reports, Government and NGOs' documentations, scholarly articles and books.

Analytical framework: All the processed information has been analyzed to fulfil the objective of the study. Both qualitative and quantitative analysis is used. Table 1 summarizes the list of variables used in the study. Descriptive statistics such as mean, standard deviation, minimum and maximum has been used to understand the socioeconomic status of the respondent. A set of statistical tools such as hypothesis testing (Table 2), correlation analysis, and multiple regressions has been applied to assess the impact of microfinance on income generation. Statistical software, such as STATA 12, has been used to perform statistical analysis in the study.

Table 1: Description of the variables of the study.

\begin{tabular}{|c|l|l|l|}
\hline SL. & \multicolumn{1}{|c|}{ Variables } & \multicolumn{1}{|c|}{ Measurement Unit } & \multicolumn{1}{c|}{ Reference } \\
\hline 1. & Age & In years & Philomina et al. (2012) \\
\hline 2. & Family size & In numbers & Philomina et al. (2012) \\
\hline 3. & Education & Years of schooling & Terano et al. $(2015)$ \\
\hline 4. & Earning members & In number & Philomina et al. $(2012)$ \\
\hline 5. & Household income & In BDT per month & Philomina et al. $(2012)$ \\
\hline 6. & Household expenditure & In BDT per month & Philomina et al. $(2012)$ \\
\hline 7. & Household savings & In BDT per month & Philomina et al. $(2012)$ \\
\hline 8. & Household investment & In BDT per month & Philomina et al. $(2012)$ \\
\hline 9. & Amount of loan & In BDT & Terano et al. $(2015)$ \\
\hline 10. & Training & Dummy (Yes $=1$, No $=0)$ & Morduch et al. (2015) \\
\hline 11. & Loan duration & In Years & Terano et al. (2015) \\
\hline 12. & Capital & In BDT & \\
\hline 13. & Working time & In Hours & \\
\hline
\end{tabular}

Table 2: Hypothesis testing of the research.

\begin{tabular}{|l|l|l|}
\hline \multicolumn{1}{|c|}{ Variables } & \multicolumn{1}{|c|}{ Null Hypothesis $\left(\mathbf{H}_{\mathbf{0}}: \boldsymbol{\gamma}=\mathbf{0}\right)$} & \multicolumn{1}{c|}{ Alternative Hypothesis $\left(\mathbf{H}_{\mathbf{1}}: \boldsymbol{\gamma} \neq \mathbf{0}\right)$} \\
\hline Income & Mean diff. $=0$ between MTB and MTA & Mean diff. $\neq 0$ between MTB and MTA \\
\hline Expenditure & Mean diff. $=0$ between MTB and MTA & Mean diff. $\neq 0$ between MTB and MTA \\
\hline Saving & Mean diff. $=0$ between MTB and MTA & Mean diff. $\neq 0$ between MTB and MTA \\
\hline Working hour & Mean diff. $=0$ between MTB and MTA & Mean diff. $\neq 0$ between MTB and MTA \\
\hline Capital & Mean diff. $=0$ between MTB and MTA & Mean diff. $\neq 0$ between MTB and MTA \\
\hline
\end{tabular}

$\mathrm{MTB}=$ Before microfinance taking and MTA $=$ After microfinance taking

A multiple log-linear regression analysis (Equation 1) has been used to was conducted to determine the significant influencing factors on the total household

UniversePG I www.universepg.com income of the microfinance recipient after joining the program (Terano et al., 2015).

$$
\ln Y=\beta_{0}+\beta_{1} X_{1 i}+\beta_{2} X_{2 i}+\beta_{3} X_{3 i}+\beta_{4} X_{4 i}+\beta_{5} X_{5 i}+\varepsilon \ldots \text { (1) }
$$


Where, $Y=$ Household income, $X_{1}=$ Age, $X_{2}=$ Years of schooling, $\mathrm{X}_{3}=$ Family member, $\mathrm{X}_{4}=$ Loan amount, $\mathrm{X}_{5}=$ Loan duration, and $\varepsilon=$ Error term, $\ln =$ Logarithmic expression, $\beta_{0}=$ Constant, and $\beta_{1}, \beta_{2}, \beta_{3}$, $\beta_{4}$, and $\beta_{5}$ are coefficients.

It is assumed in the regression analysis that loan amount is positively related to the household total income. Besides, the age of the respondent, education, family member, loan duration and training will also have a positive relationship.

\section{RESULTS AND DISCUSSION}

Socioeconomic profile: The below Table 3 provides a brief description of the socioeconomic profile of the respondents. It has been found that the average age of the respondent is 39 years. The majority of the respondent has completed the primary level. Each family has more than one earning member.

The average household income of the respondent is above BDT 150,000 per month for both microfinance taker and non-taker. Those who have taken microfinance experienced an increase in the income level aftermath. The difference between income after taking microfinance and before taking microfinance is significantly positive. In the same way, monthly household expenditure, saving, working hour and capital have been significantly increased compared to the situation of having no access to microfinance to the households who have received microfinance. As a result, the test of hypothesis through t-test provides firm ground to reject the null hypothesis that there is no difference between before microfinance and after microfinance situation in the respective variables.

Table 3: Summary statistics of the full sample, before microfinance and after microfinance.

\begin{tabular}{|c|c|c|c|c|c|c|c|}
\hline \multirow[t]{2}{*}{ Variable Name } & \multicolumn{4}{|c|}{ Descriptive Statistics } & \multirow[t]{2}{*}{ MTA } & \multirow[t]{2}{*}{ MTB } & \multirow[t]{2}{*}{ Difference } \\
\hline & Mean & S.D. & Min & Max & & & \\
\hline Age & 39.64 & 11.35 & 22 & 68 & - & - & - \\
\hline Education & 6.48 & 3.71 & 0 & 16 & - & - & - \\
\hline Earning members & 1.53 & 0.96 & 1 & 4 & - & - & - \\
\hline Household income & $15,416.67$ & $9,996.56$ & 1,500 & 50,000 & $15,179.49$ & $10,820.51$ & $4,358.97 * * *$ \\
\hline Household expenditure & $12,120.13$ & $7,919.62$ & 3,650 & 41,000 & $11,705.13$ & $9,512.82$ & $2,192.31 * * *$ \\
\hline Household savings & $2,039.10$ & $2,968.10$ & 0 & 20,000 & $1,396.15$ & 841.03 & $555.13 * * *$ \\
\hline Working hour & 61.5 & 14.68 & 30 & 126 & 49.95 & 45.26 & $4.69 *$ \\
\hline Capital & $90,589.74$ & $208,391.5$ & 0 & 1000,000 & $130,769.2$ & $50,512.82$ & $80,256.41 *$ \\
\hline
\end{tabular}

$* * *=$ significant at 1 percent level, $* *=$ significant at 5 percent level, $*=$ significant at 10 percent level, MTB $=$ Before microfinance taking and MTA = After microfinance taking.

Table 4: Correlation analysis for microfinance taker.

\begin{tabular}{|l|l|l|l|l|}
\hline Variables & Income & Expenditure & Savings & Credit \\
\hline Income & 1.00 & - & - & - \\
\hline Expenditure & $0.78^{* * *}(0.00)$ & 1.00 & - & - \\
\hline Savings & $0.63 * * *(0.00)$ & $0.78^{* * *}(0.00)$ & 1.00 & - \\
\hline Credit & $0.38^{* *}(0.02)$ & $0.29 * *(0.07)$ & $0.33^{* *}(0.04)$ & 1.00 \\
\hline
\end{tabular}

(Standard errors in parentheses) $* * *=$ significant at 1 percent level, $* *=$ significant at 5 percent level, $*=$ significant at 10 percent level]

Correlation analysis: Table 4 demonstrates the correlation between household income, expenditure, savings and credit of microfinance taker. It has been seen that the correlation coefficient of household income and credit is 0.38 , which is positive and significant at the 5 percent level. This result shows that credit through microfinance plays a positive role in increasing household income. Also, the correlation coefficient of credit and household expenditure is 0.29 
and it statistically significant at the 5 percent level. Besides, the correlation coefficient of credit and household savings is 0.33 , which is statistically significant at the 5 percent level. The estimates of correlation analysis exhibit considerable insight about the positive influence of microfinance on increasing household income, expenditure and savings.

Regression analysis: The results from the estimated regression model have been present in Table 5. The value of the coefficient of determination $R^{2}$ is 0.31 indicating that 31 percent variation in the dependent variable here household income after joining the microfinance program is explained by the independent variables, here, age, education, family member, loan amount and loan duration. Among the five explanatory variables, three variables, especially age, family member, and loan amount, has a statistically significant favorable influence on the monthly household income.

Table 5: Regression analysis for microfinance taker.

\begin{tabular}{|lrrr|}
\hline \multicolumn{1}{|c}{ Explanatory Variables } & \multicolumn{1}{c}{ Coefficients } & Standard Error & P-value \\
\hline Dependent Variable = Household income & & & \\
\hline Age & $0.016^{*}$ & 0.0083 & 0.05 \\
\hline Years of schooling & 0.0042 & 0.028 & 0.15 \\
\hline Family member & $0.106^{* *}$ & 0.043 & 0.01 \\
\hline Loan amount & $4.84 \mathrm{e}-06^{* *}$ & $2.02 \mathrm{e}-06$ & 0.02 \\
\hline Loan duration & 0.0020 & 0.018 & 0.91 \\
\hline Constant & $7.92^{*}$ & & 0.44 \\
\hline Observations & 39 & & \\
\hline Prob > F & 0.02 & & \\
\hline Mean VIF & 1.11 & & \\
\hline R-squared & 0.31 & & \\
\hline
\end{tabular}

$* * *=$ significant at 1 percent level, $* *=$ significant at 5 percent level, $*=$ significant at 10 percent level.

The results of the regression model are consistent with Mazumder and Wencong, (2013), and Rahman and Khan, (2013) where loan amount received has a significant positive impact on the monthly household income. Besides, education and family member have also a positive influence on the total income of household income in Bangladesh perspective. In the current study, the estimated result indicates loan has a positive impact on household income which is significant at 5 percent level. Besides, an increase in age per year and family member per person leads to increase the household income by 0.016 percent and 0.106 percent respectively. These results are statistically significant at 1 percent and 5 percent level respectively.

\section{CONCLUSION}

This research investigates the role of microfinance on household income generation of the microfinance takers households in south-west Bangladesh. Findings UniversePG I www.universepg.com from various statistical and econometric tools show that microfinance has a significant positive impact on rising household income level. Besides, estimated regression coefficients of age, family member, and loan amount show a positive and statistically significant role in household income determination. The microfinance recipient needs to utilize loan in a more sophisticated way so that the magnitude of return is more than current. In order to reduce widespread poverty from the rural areas of Bangladesh, it is imperative to incorporate them under the umbrella of microfinance services.

\section{ACKNOWLEDGEMENT}

The authors express their gratitude to the respondents for their co-operation in providing the required data for the study.

\section{CONFLICTS OF INTEREST}

All authors disclose no potential conflict of interest. 


\section{REFERENCES}

1. ADB, (2000). Finance for the poor: microfinance development strategy. Asian Development Bank, Manila. https://www.adb.org/sites/default/files/institutio nal-document/32094/financepolicy.pdf

2. Addae-Korankye A. (2012). Microfinance: a tool for poverty reduction in developing countries. Journal of Business and Retail Management Research. 7(1): 138-149.

3. Arora B. \& Singhal, A. (2013). A Comprehensive Literature on Impacts of Microfinance. Online International Interdisciplinary Research Journal, 3(5): 346-358.

4. Bebczuk R. N. \& Haimovich, F. 2007. MDGs and microcredit: An empirical evaluation for Latin American Countries. Documentos de Trabajo del CEDLAS. https://www.econstor.eu/handle/10419/189603

5. Chirwa E. W. (2002). Microfinance and Poverty reduction in Malawi: What has Happened to the Microfinance Revolution? http://www.eldis.org/document/A58451

6. Hermes N. \& Lensink, R. (2007). The empirics of microfinance: what do we know? The Economic Journal. 117(717): F1-F10. https://entwicklungspolitik.uni-hohenheim.de/ uploads/media/The_empirics_of_microfinanceWhat_do_we_know_03.pdf

7. Hossain MR, Khatun S, and Rashid MA. (2019). Present status of information and internet services in union council of Madhukhali upazila: a case study, Br. J. Arts Humanit., 1(6), 35-44. https://doi.org/10.34104/bjah.019.35044

8. Kaburi S. N., Ombasa, B. B., Omato, D. N., Mobegi, V. O. \& Memba, F. (2013). An Overview of the Role of Microfinance in Eradicating Poverty in Kenya: A Lesson to be learnt from the Emerging Economies. International Journal of Arts and Commerce. 2(5): 34-39.

https://ijac.org.uk/images/frontImages/gallery/V ol._2_No._5/4.pdf

9. Khan M. A. \& Rahaman, M. A. (2007). Impact of microfinance on living standards, empowerment and poverty alleviation of poor people: a case study on microfinance in the Chittagong District of Bangladesh. http://www.diva-portal.org/smash/record.jsf? pid=diva2: 141240

10. Ledgerwood J., Earne, J. \& Nelson, C. (2013). The new microfinance handbook: A financial market system perspective. The World Bank.

11. Mazumder M. S. U. \& Wencong, L. (2013). Micro-credit and poverty reduction: a case of Bangladesh. Prague Economic Papers. 22(3): 403-417. https://doi.org/10.18267/j.pep.459

12. Mazumder M. S. U. \& Wencong, L. (2015). Does Microfinance Impact on Rural Empowerment in Bangladesh? Differences between Governmental and Non Governmental Microfinance Programs. Sustainable Development. 23(3): 135-152. https://doi.org/10.1002/sd.1578

13. Morduch J. (1999). The microfinance promise. Journal of Economic Literature. 37: 1569-1614.

14. Morduch J. \& Haley, B. (2002). Analysis of the effects of microfinance on poverty reduction. NYU Wagner working paper.

https://www.findevgateway.org/paper/2001/11/a nalysis-effects-microfinance-poverty-reduction

15. Nawaz F. (2015). Microfinance, Financial Literacy, and Household Power Configuration in Rural Bangladesh: An Empirical Study on Some Credit Borrowers. Voluntas: International J. of Voluntary and Nonprofit Organizations. 26(4): 1100-1121. https://doi.org/10.1007/s11266-015-9585-z

16. Nawaz S. (2010). Microfinance and poverty reduction: evidence from a village study in Bangladesh. Journal of Asian and African studies. 45(6): 670-683. https://doi.org/10.1177/0021909610383812

17. Olivares M. \& Santos, S. (2009). Market solutions in poverty: The role of microcredit in development countries with financial restrictions. ISEG-School of Economics and Management, Department of Economics, University of Lisbon, Portugal. http://hdl.handle.net/10400.5/2542 
18. Otero M. (1999). Bringing development back, into microfinance. Journal of Microfinancel ESR Review. 1(1): 8-19.

19. Philomina Q., Emmanuel, A. \& Emmanuel, A. (2012). Influence of Micro Finance and Small Loan Centre (MASLOC) on the Development of Small Scale Enterprises in the Wa Municipality. European Journal of Business and Management. 4(1): 1-10.

20. Rahman M. A. \& Mazlan, A. R. (2014). Determinants of Financial Sustainability of Microfinance Institutions in Bangladesh. International Journal of Economics and Finance. 6(9): 107-116. https://doi.org/10.5539/ijef.v6n9p107

21. Rahman M. T. \& Khan, H. T. (2013). The effectiveness of the microcredit programme in Bangladesh. Local Economy. 28(1): 85-98. https://doi.org/10.1177/0269094212466036

22. Robinson M. (2001). The microfinance revolution: Sustainable finance for the poor. The World Bank.

23. Silva I. D. (2012). Evaluating the impact of microfinance on savings and income in Sri Lanka: Quasi-experimental approach using propensity score matching. Margin: The
Journal of Applied Economic Research. 6(1): 47-74.

https://doi.org/10.1177/097380101100600103

24. Sinha D. 1998. Economic growth and government expenditure in China.

https://mpra.ub.uni-muenchen.de/id/eprint/18 $\underline{347}$

25. Smith P. \& Thurman, E. 2007. A billion bootstraps: Microcredit, barefoot banking, and the business solution for ending poverty. McGraw Hill.

26. Terano R., Mohamed, Z. \& Jusri, J. H. H. (2015). Effectiveness of microcredit program and determinants of income among small business entrepreneurs in Malaysia. Journal of Global Entrepreneurship Research. 5(1): 22. https://doi.org/10.1186/s40497-015-0038-3

27. Ubagu MM, and Gbuushi JA. (2020). Perceived effect of motivation on the job performance of library personnel of universities in Benue state, Nigeria, Br. J. Arts Humanit., 2(1), 14-23. https://doi.org/10.34104/bjah.020014023

28. Winters P., Davis, B. \& Corral, L. (2002). Assets, activities and income generation in rural Mexico: factoring in social and public capital. Agricultural Economics. 27: 139-156.

Citation: Basu S, Roy A, and Karmokar S. (2020). Effectiveness of microfinance on household income generation strategy in the southwest region of Bangladesh, Asian J. Soc. Sci. Leg. Stud., 2(3), 56-62. https://doi.org/10.34104/ajssls.020.056062 @) क्ष 